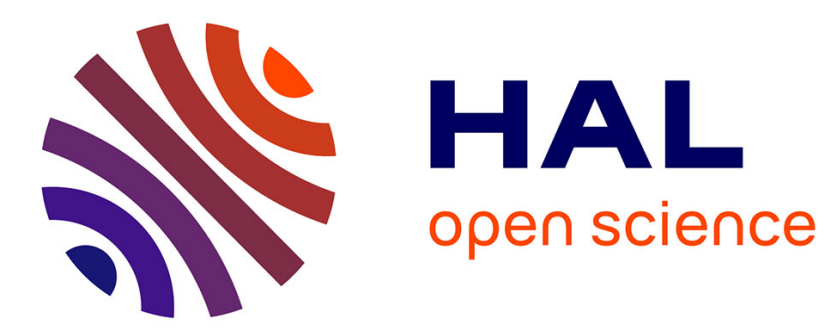

\title{
Yellow fever: the Pacific should be prepared
}

Didier Musso, Philippe Parola, Didier Raoult

\section{To cite this version:}

Didier Musso, Philippe Parola, Didier Raoult. Yellow fever: the Pacific should be prepared. The Lancet, 2018, 392 (10162), pp.2347. 10.1016/S0140-6736(18)32520-0 . hal-01970221

\section{HAL Id: hal-01970221 \\ https://hal.science/hal-01970221}

Submitted on 9 Apr 2019

HAL is a multi-disciplinary open access archive for the deposit and dissemination of scientific research documents, whether they are published or not. The documents may come from teaching and research institutions in France or abroad, or from public or private research centers.
L'archive ouverte pluridisciplinaire $\mathbf{H A L}$, est destinée au dépôt et à la diffusion de documents scientifiques de niveau recherche, publiés ou non, émanant des établissements d'enseignement et de recherche français ou étrangers, des laboratoires publics ou privés. 


\section{Yellow fever: the Pacific should be prepared}

We can anticipate the emergences of arboviruses, even if predicting them with high accuracy is impossible. ${ }^{1}$ Countries infested with Aedes (Stegomyia) aegypti mosquitoes should be prepared for detection, prevention, surveillance, and clinical management of disease transmitted by $A$ aegypti, ${ }^{1}$ especially those diseases causing severe and fatal infections and for which effective preventive measures exist, such as safe and affordable vaccines.

Yellow fever has never emerged in the Pacific, despite favourable conditions for dengue virus in this high-endemic area, such as an immunologically naive population, widespread distribution of $A$ aegypti (the main driver of urban yellow fever), a tropical climate, and increased international tourism. ${ }^{1}$

Yellow fever is endemoepidemic in sub-Saharan Africa and the Americas. ${ }^{2}$ The risk of introduction of arboviruses to the Pacific from the Americas is exemplified by the introduction of dengue virus serotype 3 (in 2013) and chikungunya virus (in 2014) to French Polynesia from the Americas, and by the introduction of Zika virus in $2015 .{ }^{1}$ The re-emergence of yellow fever in the Americas in 2016, with a new increase of cases during early 2018 and the posssibility of an urban cycle of yellow fever, increases the risk of spreading the virus to the Pacific. ${ }^{2}$

After the emergence of chikungunya virus and Zika virus in the past decade, in addition to continuous circulation of dengue virus, ${ }^{3}$ are Pacific countries and territories prepared to fight the next arboviral threat, especially yellow fever? The absence of accurate surveillance systems and diagnosis capacities in the region will delay detection of cases and clusters. The millions of people living in the region are not vaccinated against yellow fever, and they are spread across thousands of inhabited islands, which makes emergency mass vaccination campaigns logistically challenging. Whether a stockpile for reactive campaigns will be available if the demand for the yellow fever vaccine increases is uncertain. ${ }^{4}$

In 2017, WHO launched the Eliminate Yellow Fever Epidemics strategy to address the increased risk of yellow fever outbreaks in Africa and the Americas. ${ }^{4}$ The need to develop specific plans with dedicated funds is also urgent for regions where emergence of yellow fever can be dramatic, such as the Pacific and Asia, where about 2 billion people are living in $A$ aegyptiinfested countries. ${ }^{5}$

After the emergence of Zika virus in French Polynesia, we hypothesised that the virus had the potential to follow the path of dengue virus and chikungunya virus, which unfortunately has happened already. ${ }^{3}$ Our experience leads us to conclude that the world must be prepared for the worst-case scenario.

We declare no competing interests.

*Didier Musso, Philippe Parola,

Didier Raoult

dmusso@ilm.pf

Unit of Emerging Infectious Diseases, Institut Louis Malardé, Tahiti 98713, French Polynesia (DM); Unité Mixte de Recherche, Vecteurs-Infections Tropicales et Méditerranéennes, Marseille, France (DM, PP); Unité Mixte de Recherche, Microbes Evolution Phylogeny and Infections, Marseille, France (DR); and Institut Hospitalo-Universitaire Méditerranée Infection, Marseille, France (PP, DR)

1 Musso D, Rodriguez-Morales AJ, Levi JE, Cao-Lormeau V-M, Gubler DJ. Unexpected outbreaks of arboviruses infections: lessons learned from the Pacific and tropical America. Lancet Infect Dis 2018; published online June 19. https://doi.org/10.1016/S14733099(18)30269-X.

2 Douam F, Ploss A. Yellow fever virus: knowledge gaps impeding the fight against an old foe. Trends Microbiol 2018; 26: 913-28.

3 Musso D, Cao-Lormeau VM, Gubler DJ. Zika virus: following the path of dengue and chikungunya? Lancet 2015; 386: 243-44.

4 WHO. Eliminate yellow fever epidemics (EYE) by 2017-2026. Geneva: World Health Organization, 2018. http://apps.who.int/iris/ bitstream/handle/10665/272408/97892 41513661-eng.pdf?ua=1 (accessed Aug 6, 2018).

5 Wasserman S, Tambyah PA, Lim PL. Yellow fever cases in Asia: primed for an epidemic. Int J Infect Dis 2016; 48: 98-103.

\section{Disease outbreaks and reporting in Uganda}

Uganda had frequent disease outbreaks between August, 2017, and August, 2018. Therefore, identification and implementation of effective control measures are of primary concern. We present data on disease outbreaks during this time and on whether reporting according to international health regulations was adhered to by the Ministry of Health, Uganda.

Within 1 year, eight disease outbreaks occurred in Uganda (table), of which three were viral haemorrhagic fevers (VHFs; Crimean Congo haemorrhagic fever, Marburg virus disease and Rift Valley fever) that are among the prioritised zoonotic diseases for Uganda. ${ }^{1}$ The data further showed that VHFs were not reported according to international health regulations. Not reporting VHFs following these guidelines puts the population of Uganda, the travellers, tourists, and the international community at risk of a possible rapid spread of VHFs. The Global Health Security Secretariat, WHO, and the US Centers for Disease Control and Prevention need to engage the Ministry of Health, Uganda, to address the constraints that result in a failure to report VHFs. The absence of VHF reporting compromises control efforts, including public education. In previous publications, we reported VHFs and postulated the reasons for the frequent occurrence of VHFs in Uganda. ${ }^{2-5}$ Studies need to be initiated to assess the effect of environmental changes, deforestation, draining swamps, climate changes, poverty, and human-animal interaction because some of these are possible predisposing factors to frequent occurrence of disease outbreaks in Uganda.

Reporting VHFs according to international health regulations is important to enable the country to mobilise adequate resources from

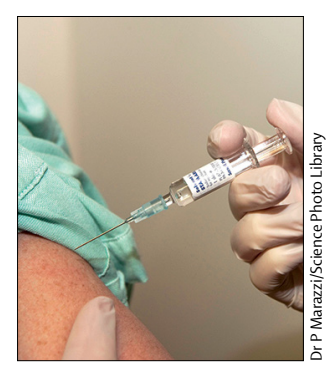

Submissions should be made via our electronic submission system at http://ees.elsevier.com/ thelancet/ 